\title{
Effects of Seasonal Weather Variability on Olive Oil Composition in Northern Italy
}

\author{
D. Tura, O. Failla, S. Pedò, C. Gigliotti \\ and D. Bassi \\ University of Milan, Dep. Crop Science \\ Via Celoria, 2 - 20133 Milano \\ Italy
}

\author{
A. Serraiocco \\ Olive and Olive Oil Research Institute \\ Contrada Fonte Umano \\ 65013 Città S. Angelo (PE) \\ Italy
}

Keywords: Olea europea, polyphenols, tocopherols, volatile compounds

\begin{abstract}
Composition and quality profiling of olive oils from two cultivars ('Casaliva' and 'Leccino') in seventeen olive groves were studied for four years (1998-2001) in "Garda Bresciano" area (western cost of lake Garda, northern Italy), in relation to seasonal weather fluctuation in term of air temperature and rainfall. Fruits from adult trees of average growth and yield were harvested individually in each orchard and the oil was extracted at fruit veraison. All oil samples were obtained by a laboratory oil mill within one day from picking. The olives were crushed, malaxed and oil was extracted by hydraulic press and separated by centrifugation. All oils were classified as "virgin". Polyphenols, tocopherols and volatile compounds were analyzed. Total polyphenols, tocopherols and volatile compounds resulted negatively correlated to maturity index, whereas 'Casaliva' cultivar was positively correlated to heat summation during olive maturation (from August to October).
\end{abstract}

\section{INTRODUCTION}

Olive oil characteristics are considered to be affected by agronomic (cultivar, environment, climate) and technological factors (Table 1). Climatic differences and seasonal weather fluctuations (temperature and rainfall) may influence the physiological behavior of the olive tree and consequently the fruit ripening process modifying both the amount and the qualitative characteristics of oil in olives (Cimato et al., 1999; Montedoro et al., 2003). For example in southern Italy, olive maturation is quicker than in the northern (Montedoro and Garofolo, 1984) and in Sardinia, comparing different sites, heat summation during maturation resulted positively correlated to olive ripening stage (Bandino et al., 1995). Panelli et al. (1994), comparing oils produced alongside six years in central Italy, found that the weather conditions, rainfall above all, influenced the quality of olive oil mainly modifying some constituents of aliphatic alcohols, head-space and phenols. Williams and Harwood (1997) have clearly shown that drought regimes, in Crete, reduced the relative activity of enzymes of lipoxygenase pathway, and consequently the volatile compounds. Aparicio et al. (1994) analyzed 53 compounds in olive oil, in Spain, and found that some fatty acids, sterols, alcohols and hydrocarbons changed systematically with altitude and hence mainly with thermal conditions. Good correlations were found by Angerosa et al. (1996) between some oil compounds (sterols, squalene, oleic acid and long-chain esters, any triacylglicerols, oleic on linoleic acid and phytol) and weather conditions (autumn temperatures, relative humidity of summer months and rainfall of whole year). Cimato et al. (1990) and Failla et al. (2002) found good correlation among polyphenols, tocopherols and maturity index.

A relationship between thermal conditions and fatty acids composition of oil which sometimes has been confirmed and sometimes not (Lotti et al., 1982; Sadeghi and Talaii, 2002), is the so called Ivanov's rule (Ivanov, 1927, 1929) which states "the amount of linoleic acid rises when the temperature decreases, contrary to oleic acid".

The present work evaluated the possible seasonal weather effects on the olive oil quality in a restricted area, close to lake Garda, which represents the northernest olive growing region in Europe. 


\section{MATERIALS AND METHODS}

\section{Oils Sampling}

Sixty-seven oil samples were obtained from 'Casaliva' and 'Leccino' cultivars (Fig. 1) in seventeen orchards in "Garda bresciano" region, in the western cost of lake Garda (Fig. 2), for four years (1998-2001). All oil samples were obtained by working about $10 \mathrm{~kg}$ of olives per tree at veraison stage within one day from picking by a standard discontinuous procedure with a laboratory oil mill. The maturity index of olives was determined by Uceda (1983) method, then the olives were crushed with an inox hammer crusher, malaxed for $30 \mathrm{~min}$ al $28^{\circ} \mathrm{C}$ and the oil was extracted by hydraulic press (max 200 bar) and separated by centrifugation at 2000rpm.

\section{Meteorological Data}

Temperatures (minimum and maximum) and rainfall data were collected daily from a meteorological station located in Sirmione (in the lake Garda southern shore) during the four years survey. The thermal trend were obtained according to the formula of heat summation on base $10^{\circ} \mathrm{C}\left(\mathrm{GDD}_{10^{\circ} \mathrm{C}}\right)$ during the olive maturation from August to October $\left(\mathrm{T}_{\max }\right.$ and $\mathrm{T}_{\min }$ are the daily maximum and minimum temperatures):

$$
\mathrm{GDD}_{10^{\circ} \mathrm{C}}=\sum_{31 \mathrm{Oct}}^{1 \text { Aug }}\left\{\left[\left(\mathrm{T}_{\max }+\mathrm{T}_{\min }\right) / 2\right]-10\right\}
$$

\section{Oil Determinations}

Oils acidity, peroxide number, $\mathrm{K}_{232}, \mathrm{~K}_{270}$ and $\Delta \mathrm{K}$ were within the limits of Commission Regulation (EC) $\mathrm{N}^{0} 1989 / 2003$, so these oils could be classified as "virgin olive oils".

1. Polyphenols Determination. The polyphenols composition was determined by HPLC modifying and adjusting the procedures describe in Cortesi and Fedeli (1983): $10 \mathrm{~g}$ oil plus $5 \mathrm{ml}$ hexane plus $6,25 \mathrm{ml}$ methanol:water (60:40) plus $0,5 \mathrm{ml} 0,01 \%$ syringic acid (Fluka) in methanol were shaken for $15 \mathrm{~min}$, then solution was centrifuged at $3000 \mathrm{rpm}$ for $10 \mathrm{~min}$ and the methanol:water phase was recuperated in a separator funnel, whereas the hexane:oil phase was extracted again 2 times; the three united methanol:water phases were washed with 7,5 $\mathrm{ml}$ hexane for 2 times and $10 \mathrm{ml}$ washed phase was evaporated on vacuum at $35^{\circ} \mathrm{C}$ and the residue was dissolved with $1 \mathrm{ml}$ methanol:water before HPLC injection. HPLC analysis: $20 \mu \mathrm{l}$ dissolved residue was injected in HPLC (CM $4000-$ Milton Roy) with RP-18 column ( $25 \mathrm{~cm} \mathrm{x} \mathrm{4,6} \mathrm{mm,} 5 \mu \mathrm{m}$ - Spherisorb) using a mobile phase gradient (A) acetonitrile:methanol and (B) $2 \%$ acetic acid in water $(2 \% \mathrm{~A}$ at $0 \mathrm{~min}$, $17 \% \mathrm{~A}$ at $20 \mathrm{~min}, 30 \% \mathrm{~A}$ at $25 \mathrm{~min}, 30 \% \mathrm{~A}$ at $30 \mathrm{~min}, 35 \% \mathrm{~A}$ at $40 \mathrm{~min}, 52 \% \mathrm{~A}$ at 45 $\mathrm{min}, 52 \% \mathrm{~A}$ at $50 \mathrm{~min}, 75 \% \mathrm{~A}$ at $60 \mathrm{~min}, 100 \% \mathrm{~A}$ at $63 \mathrm{~min}, 100 \% \mathrm{~A}$ at $68 \mathrm{~min}, 2 \% \mathrm{~A}$ at $70 \mathrm{~min}$ ), the flow rate was $1 \mathrm{ml} / \mathrm{min}$, and the detector was photodiode spectrophotometer (DAD - Waters) at $270 \mathrm{~nm}$.

2. Tocopherols Determination. The tocopherols composition was determined by HPLC modifying and adjusting the procedures describe in Micali and Currò (1984): 1,5 g oil plus $20 \mu \mathrm{l} 0,2 \%$ BHA (Merck) in hexane were dissolved with hexane:n-propanol $(99,8: 0,2)$ until $10 \mathrm{ml}$ solution. This solution was filtered (PTFE filter $02 \mu \mathrm{m}, 25 \mathrm{~mm}-$ Whatman) and $10 \mu 1$ was injected in HPLC (CM 3000 - Milton Roy) with Lichrosorb Si 60 column $(25 \mathrm{~cm} \times 4,6 \mathrm{~mm}, 5 \mu \mathrm{m}$ - Merck) using an isocratic mobile phase hexane: n-propanol $(99,8: 0,2)$, the flow rate was $2 \mathrm{ml} / \mathrm{min}$, and the detector was fluorescence spectrophotometer (1046 A - Helwlett Pakard) with a programmed wavelength: $\lambda$ ex 298 $\mathrm{nm}$ and $\lambda$ em $321 \mathrm{~nm}$ at 10,30 $\mathrm{min} ; \lambda$ ex $227 \mathrm{~nm}$ and $\lambda \mathrm{em} 314 \mathrm{~nm}$ at 17,0 min.

3. Head-Space Determination. The volatile compounds were determined by GC following the procedures describe in Angerosa et al. (1997).

\section{Statistical Analysis}

All data were submitted to statistical analysis by SPSS program (version 11.5 for 
Window - SPSS Inc. Chicago, Illinois, 2003). A general linear model was applied to compare oils form different years and cultivars. Regression and correlation models were tested for oils compositions vs. meteorological courses.

\section{RESULTS AND DISCUSSION}

\section{Seasonal Weather Conditions}

The seasonal weather conditions detected during the four year survey were characterized following daily rainfall and temperatures: 1998 recorded high rainfall in summer, and cool temperatures in spring and autumn; 1999, high rainfall in spring and autumn; 2000, low rainfall in winter, spring and summer, cool winter and summer, and warm spring; 2001, high rainfall in winter and low in autumn, and warm summer and autumn (Fig. 3). The temperature fell down the $10^{\circ} \mathrm{C}$ threshold in November.

During the olive maturation, from August to October, rainfall was always quite high all years (from 279 in 2001 to 448 in 1999), whereas a wide variation in temperature range was detected (Table 2). The heat summation on base $10^{\circ} \mathrm{C}$ were below 900 $\mathrm{GDD}_{10^{\circ} \mathrm{C}}$ with an ample range among years $\left(822-886 \mathrm{GDD}_{10^{\circ} \mathrm{C}}\right): 1998$ showed to be a rather cool year; 2000 and 2001 were the warmest; 1999 was intermediate. However, differences in the monthly fluctuation were detected: e.g. 2001 was warm in August, cool in September and cool again in October (Fig. 3).

\section{Oil Characteristics}

The olive ripening degree at harvest was always lower in 'Casaliva' than in 'Leccino'. Moreover, 'Casaliva' oils were higher in polyphenols and volatiles, whereas 'Leccino' oils were higher in tocopherols, about double, every year (Table 3).

As far as the relation among oil composition and weather conditions are considered, rainfall failed to be significant in any statistical model, while the olive maturity index and heat summation during olive maturation (from August to October) appeared to be significant as follows.

Total polyphenols resulted negatively correlated to the olive maturity index in 'Leccino' oils, while in 'Casaliva' oils, at similar olive ripening stage, polyphenols were higher in the years with the highest heat summation (Fig. 4a).

Total tocopherols resulted negatively correlated to olive maturity index: its content in 'Leccino' oils was double than in 'Casaliva' ones. The latter, at the same olive maturity index, had the highest content in the warmest years (Fig. 4b).

Volatile compounds resulted negatively correlated to olive maturity index. Moreover, in 'Casaliva' oils, deviation from this correlation was explained by heat summations during olive maturation: warmer years induced higher volatiles (Fig. 4c).

\section{DISCUSSION AND CONCLUSIONS}

The seasonal weather condition recorded in the four years varied in term of air temperature and rainfall, although within the range of the expected fluctuation of the regional climate.

Olives were generally collected in the first fifteen days of November, according to olive ripening (veraison stage) and/or meteorological conditions (night frost, early winter), so in the four years different olive maturity index resulted. In these conditions oils from both cultivars produced in the four years were significantly different in polyphenols, tocopherols and volatiles compounds.

In 'Leccino', most of the variations were due to the different ripening stage at harvest. Oils from olives harvested in a less advanced maturity stage were richer in all the constituents. In contrast, oils from 'Leccino' seemed to be insensitive to seasonal thermal course during maturation. Oils from 'Casaliva' were affected by ripening stage at harvest only to some extent in term of volatile compounds $\left(\mathrm{r}^{2}=0,591\right)$. While comparing oils from olives at similar maturity index, a significant effect of the thermal course during maturation was identified: oils from years higher in heat summation were significantly 
higher in polyphenols, tocopherols and volatiles.

Our data confirm the results of Panelli et al. (1990), which underlined that the late cultivars (e.g. 'Casaliva') are more greatly influenced by weather conditions than the early ones (e.g. 'Leccino').

\section{ACKNOWLEDGEMENTS}

Research funded by EU Commission, Regulation (EC) No 528/99, in co-operation with the Agriculture Department of Lombardy Region, Italy. The authors thank the olive growers of "Garda bresciano" area for furnishing the olive samples, and dr. Luigi Mariani for providing the meteorological data.

\section{Literature Cited}

Angerosa, F., Di Giacinto, L. and d'Alessandro, N. 1997. Quantitation of some flavor componentes responsible for the "green" attributes in virgin olive oils. J. High Resol. Chromatogr. 20: 507-510.

Angerosa, F., Di Giacinto, L., Basti, C. and Serraiocco, A. 1996. Influenza della variabile "ambiente" sulla composizione degli oli vergini di oliva. Riv. Ital. Sostanze Grasse 73: 461-467.

Aparicio, R., Ferreiro, L. and Alonso, V. 1994. Effect of climate on the chemical composition of virgin olive oil. Anal. Chim. Acta 292: 235-241.

Bandino, G., Deidda, P., Nieddu, G., Spano, D. and Chessa, I. 1995. Maturazione delle olive e qualità dell'olio in relazione alle condizioni ambientali. Proc. "Olivicoltura mediterranea: stato e prospettive della coltura e della ricerca". Rende (CS), Italy 26-28 January: 649-656.

Cimato, A., Baldini, A. and Moretti, R. 1999. L'olio di oliva-Cultivar, ambiente e tecniche agronomiche - Parte $2^{\mathrm{a}}$. A.R.S.I.A., Regione Toscana (Italy).

Cimato, A., Sani, G., Mattei, A. and Osti, M. 1990. Cultivars and environmental as regulating factors in polyphenol and tocopherol contents of the Tuscan oil. Acta Hort. 286: 457-460.

Commission Regulation (EC) $\mathrm{N}^{\mathrm{o}} 1989 / 2003$ of 6 November 2003. Amending Regulation (EEC) $\mathrm{N}^{0} 2568 / 91$ on the characteristics of olive oil and olive-pomace oil and on the relevant methods of analysis. Off. J. Eur. Union L295: 57-77.

Cortesi, N. and Fedeli, E. 1983. I componenti polari di oli di oliva vergine. Nota 1. Riv. Ital. Sostanze Grasse 60: 341-345.

Cortesi, N., Fedeli, E. and Rovellini, P. 1990. I trigliceridi degli oli di oliva. Nota II. Riv. Ital. Sostanze Grasse 67: 127-129.

Failla, O., Tura, D. and Bassi, D. 2002. Genotype-environment-year interaction on oil antioxidants in an olive district of northern Italy. Acta Hort. 586: 171-174.

Ivanov, S. 1927. Dependence of the chemical composition of oil containing plants on the climate. Oil \& Fat Ind. 5: 29.

Ivanov, S. 1929. The factors in the process of oil formation in plants. Osterr. Chem. Ztg. 32: 89 .

Lotti, G., Izzo, R. and Riu, R. 1982. Influenza del clima sulla composizione acidica e sterolica degli oli di oliva. Riv. Soc. Ital. Sci. Alimentazione 2: 115-126.

Micali, G. and Currò, P. 1984. Determinazione dei tocoferoli negli oli vegetali mediante HPLC. Riv. Ital. Sostanze Grasse 61: 95-98.

Montedoro, G.F. and Garofolo, L. 1984. Caratteristiche qualitative degli oli vergini di oliva. Influenza di alcune variabili: varietà, ambiente, conservazione, estrazione, condizionamento del prodotto finito. Riv. Ital. Sostanze Grasse 61: 157-168.

Montedoro, G.F., Servili, M. and Panelli, G. 2003. Le caratteristiche del prodotto e le relazioni con le variabili agronomiche. p.263-289. In: P. Fiorino (ed.), Olea - Trattato di olivicoltura. Edagricole, Bologna (Italy).

Panelli, G., Famiani, F., Servili, M. and Montedoro, G.F. 1990. Agro-climatic factors and characteristics of the composition of virgin olive oils. Acta Hort. 286: 477-480.

Panelli, G., Servili, M., Selvaggini, R., Baldioli, M. and Montedoro, G.F. 1994. Effect of 
agronomic and seasonal factors on olive (Olea europea L.) production and on the qualitative characteristics of the oil. Acta Hort. 356: 239-244.

Sadeghi, H. and Talaii, A.R. 2002. Impact of environmental conditions on fatty acids combination of olive oil in an Iranian olive, cv. Zard. Acta Hort. 586: 579-581.

Uceda, M. 1983. Factores que influyen en la calidad del aceite de oliva. Simposio Expoliva 83, Jaen (Spain).

Williams, M. and Harwood, J.L. 1997. Effect of drought on volatile production by the lipoxygenase pathway in olive fruit. Biochememical Society Transactions 25: 499S.

\section{Tables}

Table 1. Influences of agronomic factors on olive oil quality by literature cited.

\begin{tabular}{|c|c|}
\hline Agronomic factor & Effect on olive oil quality \\
\hline $\begin{array}{l}\text { Cultivar and } \\
\text { Environment }\end{array}$ & $\begin{array}{l}\text { Deviation between triglycerides content by HPLC and by theorical determination } \\
\text { depends from cultivar, climatic and soil differences (Cortesi et al., 1990). } \\
\text { Late cultivars are more greatly influenced by climate (Panelli et al., 1990). }\end{array}$ \\
\hline Altitude & $\begin{array}{l}\beta \text {-sitosterol, cycloarthenol, 24-methylencycloarthanol, copaene, palmitoleic and linoleic } \\
\text { acids result to be the most related oil compounds to altitude (Aparicio et al., 1994). }\end{array}$ \\
\hline Weather conditions & $\begin{array}{l}\text { Amount of linoleic acid rises when the temperature decreases, contrary to oleic acid } \\
\text { (Ivanov., } 1927 \text { and 1929). } \\
\text { In cooler climate: oil yield decreases, oleic acid increases, and linoleic, palmitic, } \\
\text { palmitoleic and stearic acids decrease slightly (Lotti et al., 1982). } \\
\text { Oleic acid is higher where climate is rather cooler, while polyunsaturated fatty acids } \\
\text { increase when temperature is warmer (Sadeghi and Talaii, 2002). } \\
\text { Aliphatic alcohols, head-space compounds and phenols are modified mainly from } \\
\text { rainfall trend during growing and ripening of olive fruits (Panelli et al., 1994). } \\
\text { Total sterols, squalene, oleic esters, long chain esters, some triglycerides, oleic on } \\
\text { linoleic acid ratio and phytol are positively correlated to autumnal temperatures, } \\
\text { summer relative humidity and total rainfall (Angerosa et al., 1996). } \\
\text { Many volatiles in oil decease because activity of enzymes of lipoxygenase pathway in } \\
\text { fruits is altered by drought (Williams and Harwood, 1997). }\end{array}$ \\
\hline Olive maturation & $\begin{array}{l}\text { Total polyphenols and volatile compounds increase with olive maturation until skin } \\
\text { veraison stage, when they decrease. Phenols and volatiles decrease in oils obtained } \\
\text { from olives stored before oil extraction than in those from olives worked soon after } \\
\text { picking. Crushing and malaxation interfere on extraction of olives compounds in oil } \\
\text { (Montedoro and Garofolo, 1984). } \\
\text { Polyphenols and tocopherols are higher during first period of harvesting and gradually } \\
\text { decline as fruits ripen, irrespective of environment and cultivar (Cimato et al., 1990). } \\
\text { Total polyphenols and panel test scores of different cultivar oils decrease with olives } \\
\text { maturation. Heat summation of maximum and average temperatures result positively } \\
\text { and significantly correlated to olive maturation (Bandino et al., 1995). } \\
\text { Total polyphenols and tocopherols increase with olives maturation (Failla et al., 2002). }\end{array}$ \\
\hline
\end{tabular}


Table 2. Characteristics of seasonal weather conditions from August to October.

\begin{tabular}{lcccc}
\hline & 1998 & 1999 & 2000 & 2001 \\
\hline Heat summation Aug-Oct $\left(\mathrm{GDD}_{10^{\circ} \mathrm{C}}\right)$ & 822 & 865 & 879 & 886 \\
Rainfall Aug-Oct $(\mathrm{mm})$ & 333 & 448 & 364 & 279 \\
\hline
\end{tabular}

Table 3. Olive oils characteristics of the two cultivars in the four investigated years.

\begin{tabular}{|c|c|c|c|c|c|c|c|c|}
\hline & \multicolumn{4}{|c|}{ CASALIVA } & \multicolumn{4}{|c|}{ LECCINO } \\
\hline & 1998 & 1999 & 2000 & 2001 & 1998 & 1999 & 2000 & 2001 \\
\hline Maturity Index & $2,10 \mathrm{~b}$ & 0,96 a & $1,95 \mathrm{~b}$ & $0,85 \mathrm{a}$ & $3,43 \mathrm{c}$ & $2,86 \mathrm{~cd}$ & $2,52 \mathrm{bc}$ & $2,08 \mathrm{~b}$ \\
\hline Total polyphenols (mg/kg) & $171 \mathrm{~b}$ & $197 \mathrm{~b}$ & $381 \mathrm{c}$ & $335 \mathrm{c}$ & $140 \mathrm{a}$ & 128 a & $185 \mathrm{~b}$ & $193 \mathrm{~b}$ \\
\hline Total tocopherols (mg/kg) & $104 \mathrm{a}$ & $119 \mathrm{ab}$ & $144 \mathrm{bc}$ & $157 \mathrm{c}$ & $232 \mathrm{~d}$ & $296 \mathrm{e}$ & $298 \mathrm{e}$ & $319 \mathrm{f}$ \\
\hline Total volatile compounds (mg/kg) & $460 \mathrm{a}$ & $1425 \mathrm{c}$ & $1438 \mathrm{c}$ & $1992 \mathrm{~d}$ & $314 \mathrm{a}$ & $1169 \mathrm{~b}$ & $1371 \mathrm{c}$ & $1622 \mathrm{c}$ \\
\hline
\end{tabular}

Figures

\begin{tabular}{|l|l|l|}
\hline & CASALIVA \\
& Tree: good yield and low frost resistance.
\end{tabular}

Fig. 1. Characteristics of the olive cultivars on trial.

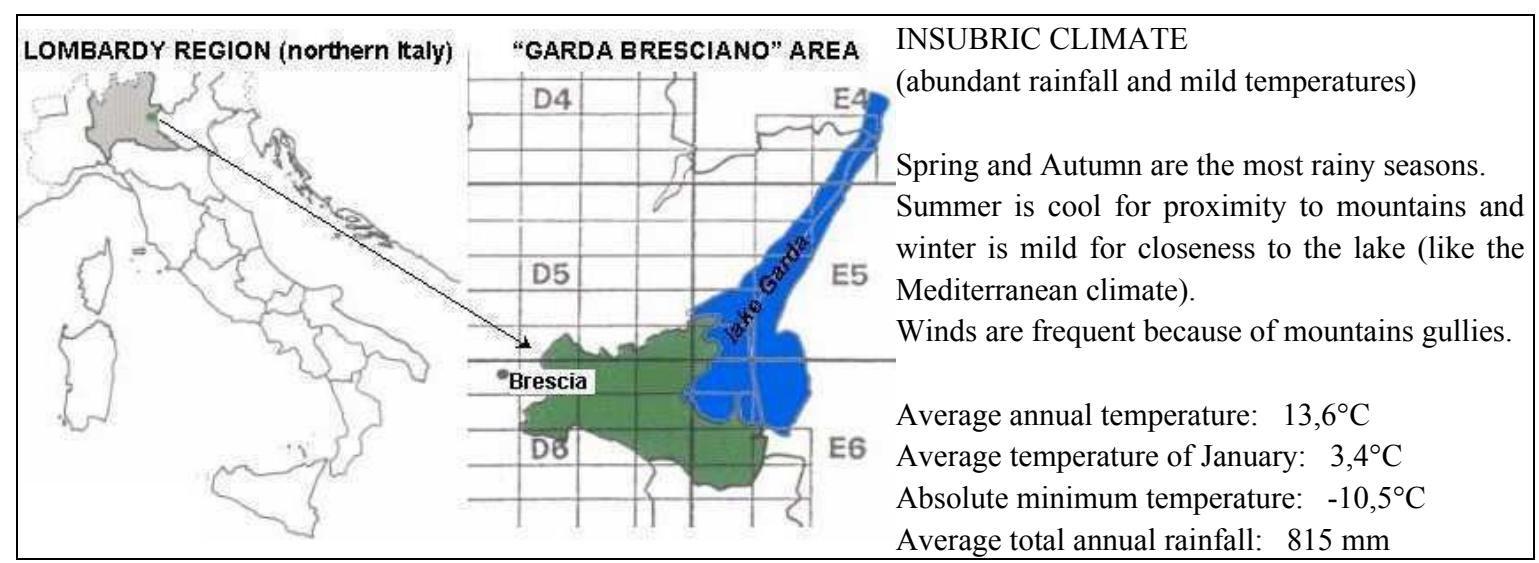

Fig. 2. Geographic position and climatic characteristics of "Garda bresciano" area. 


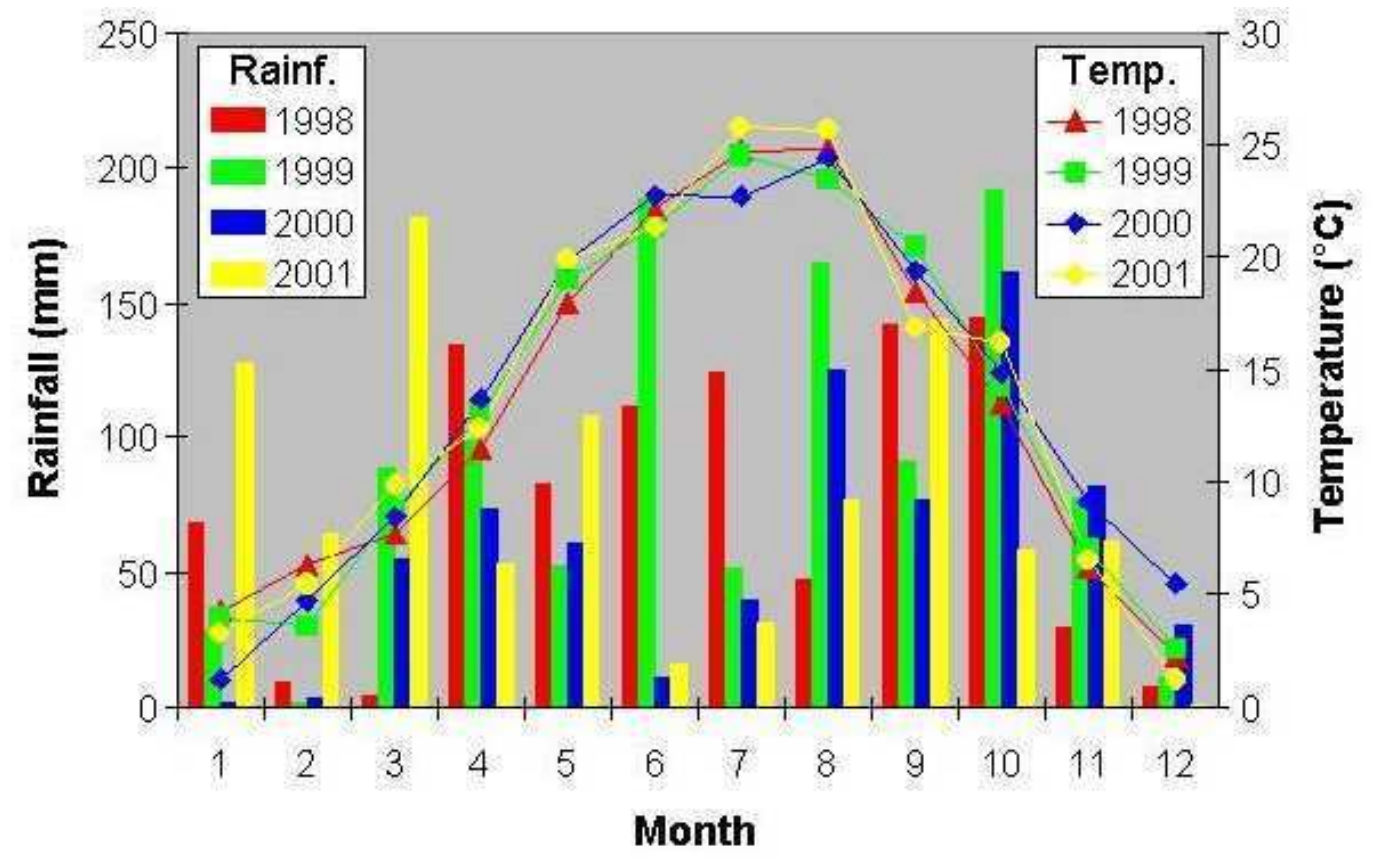

Fig. 3. Seasonal weather conditions during the four year survey. 


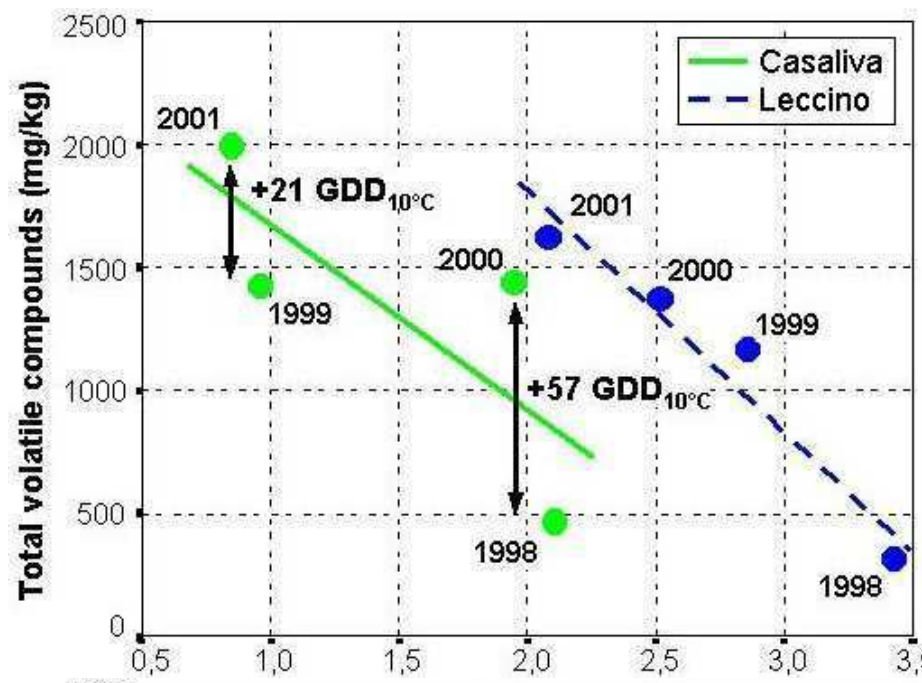

Fig. 4a

Bivaried correlation between total polyphenols and maturity index:

Casaliva $\mathrm{r}=-0,061^{\mathrm{n}}$.

Leccino $\quad \mathrm{r}=-0,812 *$

Partial correlation between total polyphenols and heat summation: Casaliva $\quad \mathrm{r}=0,969$ *

Leccino $\quad r=-0,457^{\text {n.s. }}$

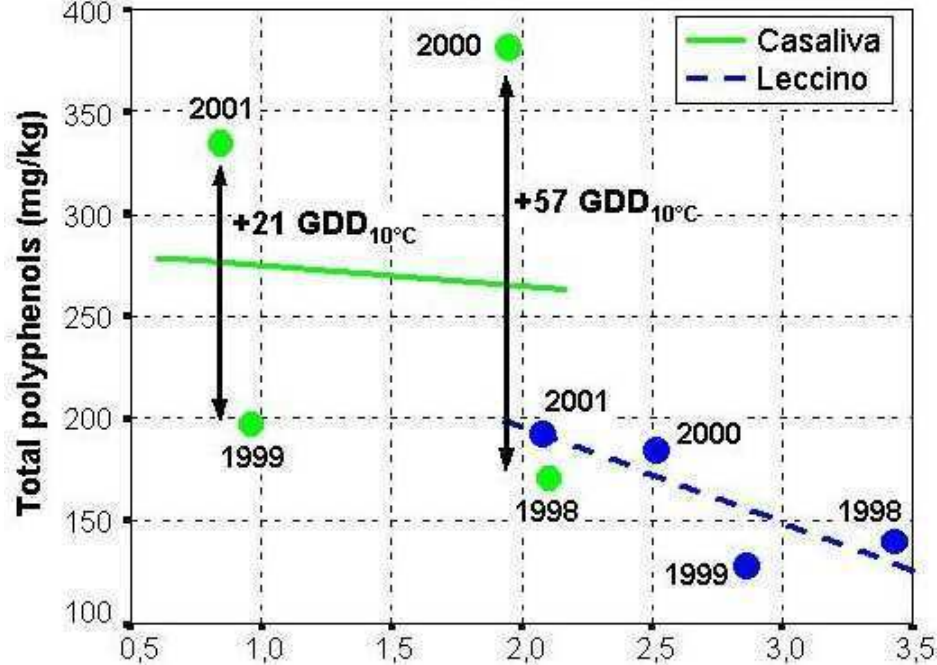

Fig. $4 b$

Bivaried correlation between total tocopherols and maturity index:

Casaliva $\mathrm{r}=-0,446^{\mathrm{n} .}$

Leccino $\quad \mathrm{r}=-0,940$ *

Partial correlation between total tocopherols and heat summation:

Casaliva $\mathrm{r}=0,969$ *

Leccino $\quad r=0,823^{\text {n.s. }}$

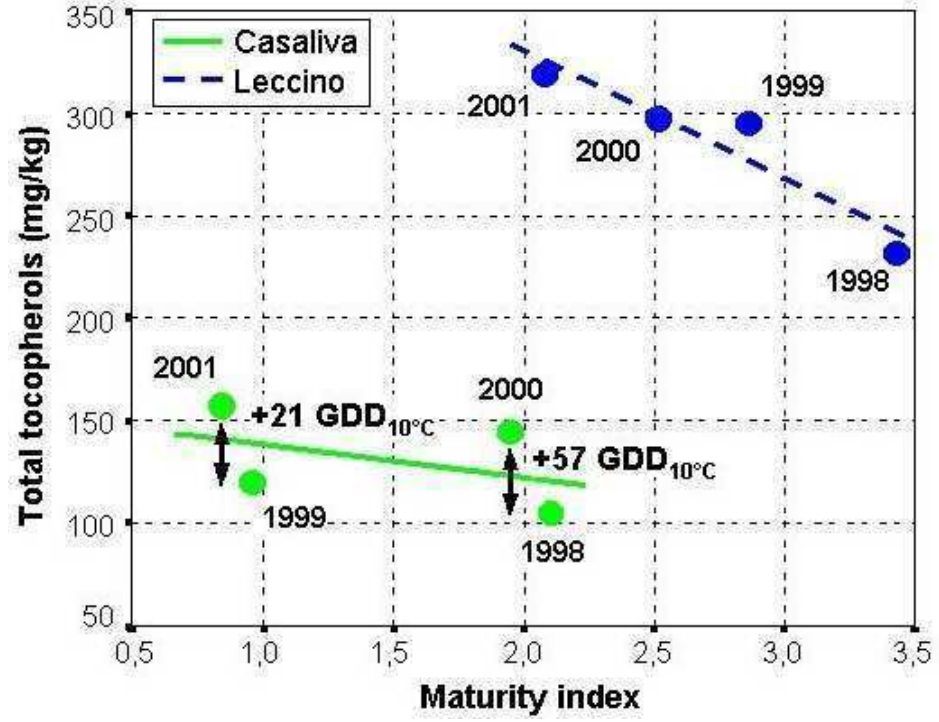

Fig. $4 \mathrm{c}$

Bivaried correlation between total volatiles and maturity index:

Casaliva $\quad r=-0,769^{n . s}$

Leccino $\quad \mathrm{r}=-0,965 *$

Partial correlation between total volatiles and heat summation:

$\begin{array}{ll}\text { Casaliva } & \mathrm{r}=0,984^{*} \\ \text { Leccino } & \mathrm{r}=0,960^{\text {n.s. }}\end{array}$

Fig. 4. Correlations between total polyphenols (4a), total tocopherols (4b), total volatile compounds $(4 \mathrm{c})$ in oils and olive maturity index: arrows highlight the deviation from the regression line due to the year heat summations.

On the right the bivaried and the partial correlation coefficients are reported. 


\section{EFFECTS OF SEASONAL WEATHER CONDITIONS ON OLIVE OIL QUALITY IN NORTHERN ITALY}

D. Turaa , O. Faillaa, S. Pedòa, C. Gigliottia , A. Serraiocco b and D. Bassia
$\begin{aligned} & \text { a - University of Milan - via Celoria, } 2 \text { - } 20133 \text { Milano, Italy - Debora.Tura@unimi.it } \\ & b \text { - Olive Oil Institute - contrada Fonte Umano - 65013 Città S. Angelo (PE), Italy }\end{aligned}$

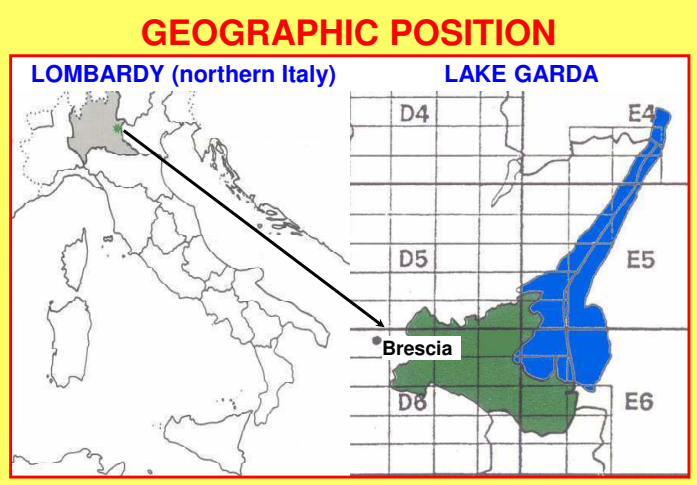

CHARACTERISTICS OF OLIVE CULTIVARS CASALIVA

Agronomic proprieties: good productivity and low frost resistance. Oil characteristics: low content in tocopherols, medium in polyphenols and volatiles; high green notes and fruity, medium in bitter and pungent

\section{CHARACTERISTICS OF "GARDA BRESCIANO” CLIMATE}

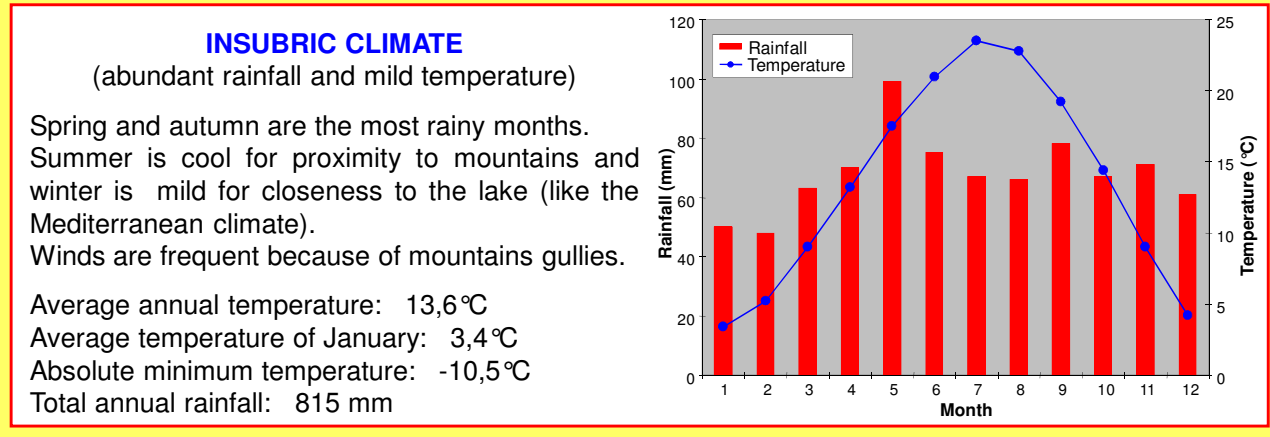

EXPERIMENTAL DESIGN

OILS SAMPLING and CLIMATIC DATA

67 oil samples from 2 olive cultivars in 17 olive groves of "Garda bresciano" area for 4 years (1998-2001). Temperature and rainfall data collected from meteorological station during the 4 year survey.

ANALYTICAL and STATISTICAL ANALYSES

Polyphenols, tocopherols and volatiles analyses.

Data processed by GL and regression models.

\section{RESULTS AND DISCUSSIONS}

\section{OIL CHARACTERISTICS IN THE YEARS}

At harvest the olive ripening degree was always lower in Casaliva than in Leccino. Casaliva oils were higher in polyphenols and volatiles, whereas Leccino oils were higher in tocopherols (about double) every years.

\begin{tabular}{lcccccccc}
\hline & \multicolumn{1}{c}{ CASALIVA } & \multicolumn{4}{c}{ LECCINO } \\
& 1998 & 1999 & 2000 & 2001 & 1998 & 1999 & 2000 & 2001 \\
\hline Maturity Index & $2,10 \mathrm{~b}$ & $0,96 \mathrm{a}$ & $1,95 \mathrm{~b}$ & $0,85 \mathrm{a}$ & $3,43 \mathrm{c}$ & $2,86 \mathrm{~cd}$ & $2,52 \mathrm{bc}$ & $2,08 \mathrm{~b}$ \\
Total polyphenols $(\mathrm{mg} / \mathrm{kg})$ & $171 \mathrm{~b}$ & $197 \mathrm{~b}$ & $381 \mathrm{c}$ & $335 \mathrm{c}$ & $140 \mathrm{a}$ & $128 \mathrm{a}$ & $185 \mathrm{~b}$ & $193 \mathrm{~b}$ \\
Total tocopherols $(\mathrm{mg} / \mathrm{kg})$ & $104 \mathrm{a}$ & $119 \mathrm{ab}$ & $144 \mathrm{bc}$ & $157 \mathrm{c}$ & $232 \mathrm{~d}$ & $296 \mathrm{e}$ & $298 \mathrm{e}$ & $319 f$ \\
Total volatile compounds $(\mathrm{mg} / \mathrm{kg})$ & $460 \mathrm{a}$ & $1425 \mathrm{c}$ & $1438 \mathrm{c}$ & $1992 \mathrm{~d}$ & $314 \mathrm{a}$ & $1169 \mathrm{~b}$ & $1371 \mathrm{c}$ & $1622 \mathrm{c}$ \\
\hline
\end{tabular}

\section{POLYPHENOLS}

\section{SEASONAL WEATHER CONDITIONS}

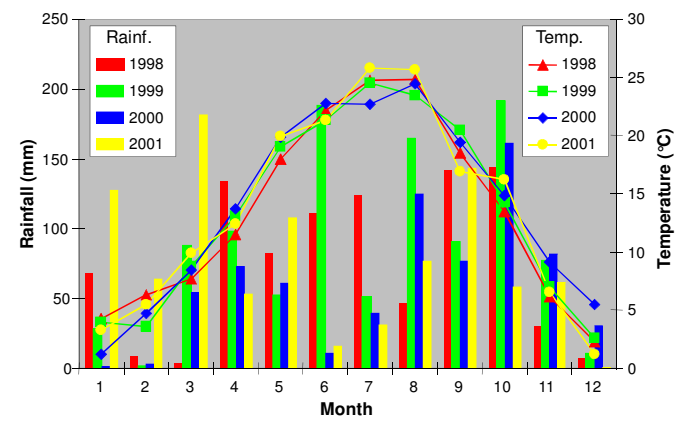

1998: higher rainfall in summer;

cooler temperatures in spring and autumn.

1999: higher rainfall in spring and autumn.

2000: lower rainfall in winter, spring and summer; cooler winter and summer, warmer spring.

2001: higher rainfall in winter and lower in autumn; warmer summer and autumn.

\begin{tabular}{lrrrrr}
\hline & 1998 & 1999 & 2000 & 2001 \\
\hline Heat summation Aug-Oct $\left(\mathrm{GDD}_{10}{ }^{\circ} \mathrm{C}\right)$ & 822 & 865 & 879 & 886 \\
Rainfall Aug-Oct $(\mathrm{mm})$ & 333 & 448 & 364 & 279 \\
\hline
\end{tabular}

During olive maturation (from August to October) a wide variation in thermal and rain conditions was detected. 1998 was a rather cool year, 2000 and 2001 were the warmest. 1999 was intermediate.

Rainfall was always quite high.

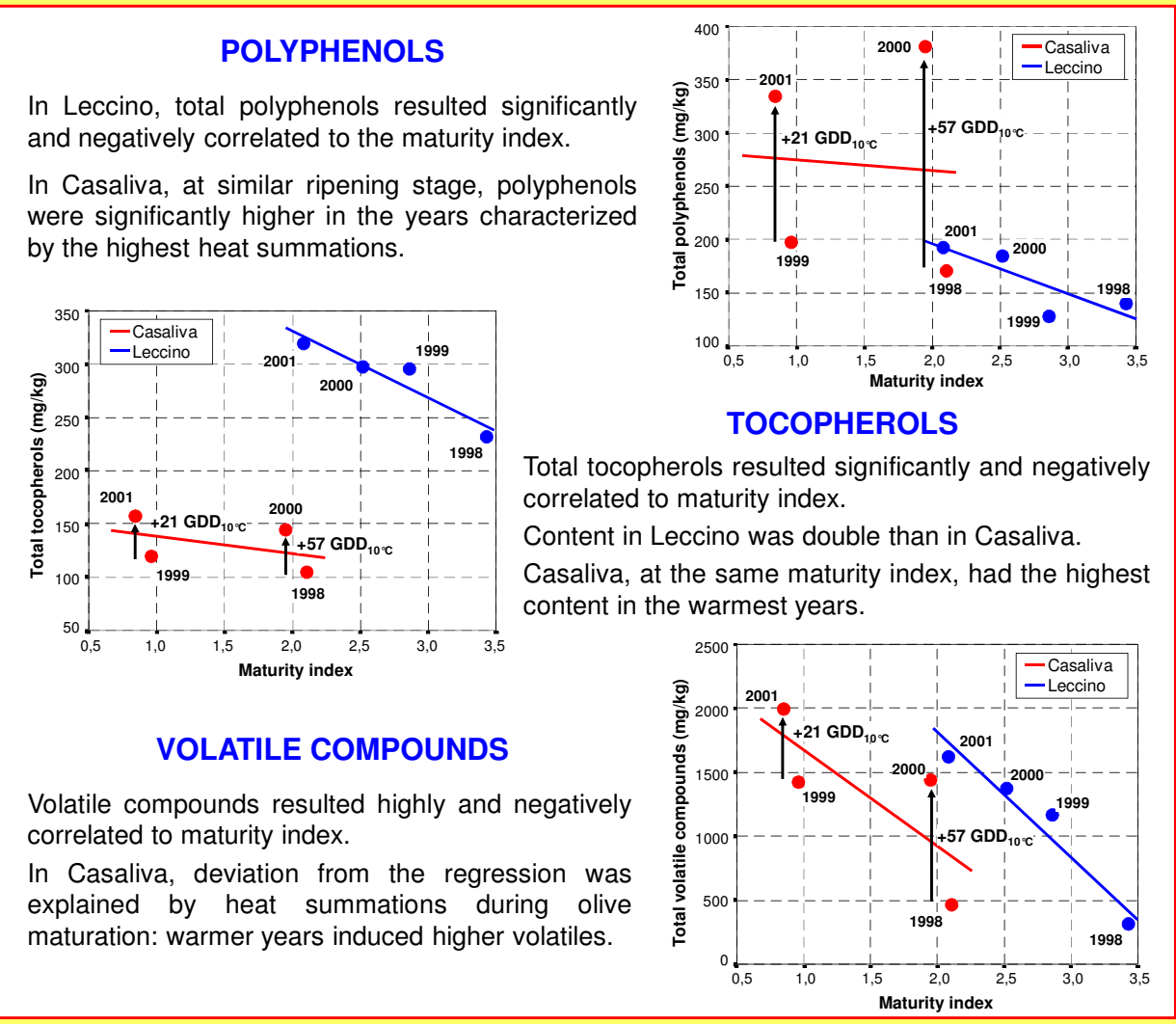

\section{CONSIDERATIONS AND CONCLUSIONS}

- The present survey considered 2 cultivars $\times 4$ years $\times 8$ sites representative of "Garda bresciano" area.

- Oils from both cultivars produced in the four years were significantly different in polyphenols, tocopherols and volatiles compounds.

- Oils from olives harvested in a less advanced maturity stage were higher in polyphenols, tocopherols and volatiles in both cultivars.
- In Leccino, most of the variation in polyphenols, tocopherols and volatiles was due to the different ripening stage at harvest. Oils from Leccino seemed to be insensitive to seasonal thermal course during maturation.

- Oils from Casaliva resulted affected also by thermal course during maturation: comparing oils form olives at the same maturity index, years higher in heat summations were significantly higher in polyphenols, tocopherols and volatiles. 